\title{
Problemy składniowe w tekstach naukowych studentów filologii germańskiej: Kilka uwag o specyfice pisarstwa naukowego w języku niemieckim jako obcym ${ }^{1}$
}

\begin{abstract}
Syntactic problems in academic texts of students of German Studies. A few Comments on the specifics of the academic writing in German as a foreign language
\end{abstract}

\author{
Monika SCHÖNHERR \\ Uniwersytet Zielonogórski/ University of Zielona Góra \\ E-mail: MonikaSchoenherr@gmx.de
}

\begin{abstract}
The purpose of the following paper is to reflect on the importance of academic writing in higher education and to discuss some difficulties both in the teaching process and practical implementation. For many students studying German as a second language producing academic texts in German is a daunting and ,painful“" task. The complexity of the writing process often leads to many linguistic problems, especially in the area of the vocabulary, grammar and syntax. Why is academic writing so difficult for many students? One of many reasons is that the students haven't enough practice in using what they have learned during their studies. Therefore, practising the academic writing skills should be supported at all levels within entire the higher education.
\end{abstract}

Keywords: academic writing, academic texts, scientific language, German as foreign language, syntax, syntactic problems

\section{Wstęp}

Infosfera współczesnego człowieka, czyli środowisko nabywania i kształtowania przez niego informacji i wiedzy, jest naznaczona zjawiskiem głębokich przemian w paradygmacie medialnym. Przemiany te wynikają min. z ogromnej liczby innowacji w zakresie techniki telewizyjnej, komputerowej $\mathrm{i}$ informatycznej. O ile wcześniejsze pokolenia były kształcone i kształtowane w monokulturze słowa pisanego, o tyle dziś tekst pisany ustępuje miejsca innym formom komunikacji (zob. L. Cirko 2009: 184), takim jak np. media audiowizualne, które wiążą się z prymatem obrazu i dźwięku. Nie da się jednak zaprzeczyć, że teksty pisane są najtrwalszym środkiem przekazu informacji, ale też skutecznym narzędziem stabilizacji wzorców budowy tekstu, norm poprawności stylistyczno-leksykalnej i wyczucia estetycznego. Czy owa wzorcotwórcza rola teksu pisanego została nadszarpnięta także we współczesnym dyskursie naukowym? Czy doszło tu także do daleko idących przeobrażeń? O ile transfer wiedzy fachowej w obrębie danej scientific community odbywa się nadal za pomocą języka w

\footnotetext{
${ }^{1}$ Przedstawione badania zostały przeprowadzone w ramach projektu „Interdyskurs. Międzykulturowe badania tekstów akademickich" przy wsparciu Narodowego Centrum Nauki (Program Harmonia).
} 
postaci tekstu pisanego, co pozwala min. na włączenie wygenerowanych wyników badań do mainstreamu naukowego, o tyle kompetencje tekstowe studentów - szczególnie w obrębie obcojęzycznych filologii - dalekie są od oczekiwań. Pisanie nie jest dziś domeną pracy studenta. W praktyce glottodydaktycznej pisanie traktowane jest jako sprawność wtórna, czasochłonna i w gruncie rzeczy mało przydatna w komunikacji (zob. T. Zuchewicz 2002: 184). Abstrahując od elementarnych problemów natury językowej, jakimi obarczony jest student filologii obcojęzycznej, należy zwrócić uwagę także na inny czynnik współodpowiedzialny za taki stan rzeczy. Jak konkluduje D. Olszewska (2009: 173), dzisiejszy student nie ma w czasie edukacji akademickiej okazji na refleksję na temat językowych form komunikacji naukowej, a co za tym idzie, nie ma też szansy na opanowanie schematów organizacji tekstów naukowych z charakterystycznymi dla nich konwencjami i rutynami w zakresie stylistyki, składni czy leksyki. Dla wielu przyszłych adeptów kierunków neofilologicznych praktyka pisania tekstu w języku obcym rozpoczyna się dopiero w momencie przystąpienia do redagowania prac dyplomowych, a zatem dopiero po piątym semestrze studiów, po czym następuje przerwa aż do semestru dziewiątego, czyli do zainicjowania prac $\mathrm{w}$ ramach seminarium magisterskiego. Obserwując powyższe fakty, nasuwa się wniosek, iż pisanie elaboratów naukowych stało się w dydaktyce uczelnianej niemodne, niewygodne, czy wręcz nie mające racji bytu.

W świetle powyższych ustaleń możemy stwierdzić, że (na-)pisanie pracy naukowej przez studenta, w szczególności przez studenta neofilologii, wiąże się nie tylko z opanowaniem wiedzy fachowej na zadany temat (i) czy też umiejętności intelektualnych takich jak analizowanie i selekcjonowanie informacji, argumentowanie i myślenie analityczne (,conceptual and cognitive involvement”, E. Guz 2016: 77) (ii), ale także z nabyciem kompetencji tekstowych, czyli umiejętnością przekazania treści zgodnie z wymogami gatunkowymi tekstu naukowego (iii). Liczne badania dowiodły, że wykonanie zadań naukowo-badawczych składających się na proces tworzenia tekstu naukowego jest dla studenta-nowicjusza punktem zwrotnym, albowiem musi on uaktywnić zupełnie nowy proces myślowy, za pomocą którego będzie w stanie przyswoić sobie modele i teorie naukowe, metody badawcze oraz właściwy im styl językowy, a w szczególności specyficzną wiedzę leksykalno-gramatyczną języka danej dyscypliny (zob. I. Leki/ A/ Cumming/ T. Silva 2008).

W dalszej części rozważań problematyka kompetencji tekstowych zostanie zawężona tylko do kwestii poprawności tekstu naukowego pod względem syntaktycznym. Zarysowane zostaną min. typowe błędy w budowie zdania, szyku oraz niedostosowaniu schematów zdaniowych do potrzeb komunikacji naukowej. Analiza przykładów źródłowych, na których opiera się badanie, nie jest jednak ukierunkowana tylko i wyłącznie na zidentyfikowanie poszczególnych deficytów, lecz raczej na wskazanie przyczyn ich powstania i sposobu ich eliminowania. Korpus tekstów źródłowych obejmuje prace licencjackie i magisterskie, złożone przez polskich studentów germanistyki w latach 2010-2015.

\section{Gramatyka stylu naukowego}

Jeśli przyjmiemy, że język nauki jest diafazycznym (komunikacyjno-stylistycznym) 
wariantem danego języka etnicznego, to reguły stosowania w nim struktur gramatycznych podlegają takim samym zasadom systemowym jak inne jego warianty funkcjonalne. Mówiąc prościej: ani morfo-syntaks ani pisownia czy artykulacja nie odbiegają jakościowo od języka ogólnego. Odseparowanie języka naukowego od języka ogólnego sygnalizuje natomiast terminologia fachowa, która uchodzi za najbardziej charakterystyczny wykładnik stylu naukowego i jest permanentnie modyfikowana, aby zoptymalizować proces wytwarzania i komunikowania (nowych) treści fachowych (zob. L. Cirko 2013: 72 i nast.).

O ile płaszczyzna leksyki w dyskursie naukowym należy do tych przestrzeni, które nieustannie ekspandują, o tyle struktura syntaktyczna dyskursu naukowego nie wykazuje tendencji do zmian jakościowych. Naukowcy zgodnie przyznają, że dyskurs naukowy nie zawiera odrębnych struktur zdaniowych (zob. D. Olszewska 2009: 164 i nast.). Różnice w stosunku do wariantu języka ogólnego mają charakter wyłącznie frekwencyjny, tzn. polegają z jednej strony na preferencyjnym i specyficznym użyciu określonych struktur zdaniowych i form gramatycznych, a z drugiej na unikaniu lub ograniczenia zasobu tych form, które pod względem konwencjonalno-stylistycznym nie odpowiadają właściwościom dyskursu naukowego. Spośród faworyzowanych konstrukcji zwraca uwagę duży udział formacji zdaniowych, które gwarantują kondensację stylu (zob. H.L. Kretzenbacher 1991). Syntaktycznym „kompresorem” jest tu min. strategia nominalizacji i związana z nią desemantyzacja czasowników, w wyniku której najważniejsze informacje przerzucane są na struktury nominalne - stąd tak częste użycie w tekście naukowym przydawek rozszerzonych, formacji słowotwórczych należących do grupy nomina actionis itp.

Ważną konsekwencją owej desemantyzacji czasowników jest eliminacja finitywnych form czasownika na rzecz form bezosobowych oraz strony biernej ze zredukowaną strukturą walencyjną czasowników, która umożliwia wykluczenie agensa ze struktur powierzchniowych zdania (zob. D. Olszewska 2009: 165). Podsumowując, można wysunąć wniosek, że gramatyka stylu naukowego w obszarze składni zdania cechuje się wybiórczością, czyli stosowaniem wybranych schematów konstrukcyjnosyntaktycznych, umożliwiających kompresję stylu.

\section{Implikacje dydaktyczne}

Wobec charakterystycznego dla czasów współczesnych obniżania się wartości naukowej i poziomu językowego prac studenckich, troska o adekwatną popularyzację stylu naukowego wydaje się być bardzo aktualna (zob. S. Gajda 2001: 192 i nast.). Z drugiej strony, ważnym dezyderatem jest dziś także systematyczna ewaluacja umiejętności tworzenia tekstów naukowych przez nowicjuszy i zdeterminowana reakcja na pogłębiające się deficyty w piśmiennictwie akademickim. Tym ostatnim zagadnieniom poświęcony jest min. projekt pt. „Interdyskurs. Międzykulturowe badania tekstów akademickich", realizowany w ramach trilateralnej współpracy przez Uniwersytet Wrocławski, Uniwersytet Ruhry w Bochum i Uniwersytet Zielonogórski dzięki wsparciu Narodowego Centrum Nauki.

Przedmiotem badań prac okołoprojektowych jest min. analiza tekstów polskich studentów germanistyki pod kątem deficytów językowych generowanych na skutek 
nieopanowania typowych dla niemieckiego piśmiennictwa naukowego schematów językowo-komunikacyjnych, ale także pod kątem przenoszenia własnych konwencji kulturowych na proces tworzenia tekstów pisanych w języku niemieckim jako języku obcym. Te ostatnie różnice można zaobserwować już na płaszczyźnie makrostrukturalnej, gdzie stopień sformalizowania organizacji tekstu w polskiej konwencji piśmienniczej jest mniejszy aniżeli w niemieckim dyskursie naukowym.

Krótko mówiąc, prace polskich studentów posiadają tendencję do jednolitej, płaskiej organizacji tekstu, co przekłada się np. na niewielką ilość rozdziałów, podczas gdy w niemieckim dyskursie zaobserwować można dążenie do hierarchicznego podziału tekstu, co skutkuje wyodrębnieniem poszczególnych aspektów merytorycznych poprzez wprowadzenie szczegółowego podziału na rozdziały i podrozdziały. Podobnych różnic w budowie tekstu motywowanych socjokulturowo jest bardzo dużo (zob. min. M. Clyne 1987). Jakkolwiek byłyby one interesujące, naszą uwagę chciałabym skupić - zgodnie z tematem artykułu - na deficytach w zakresie składni zdania, jakie ujawniają się $\mathrm{w}$ procesie tworzenia prac dyplomowych. Błędy te tylko w nieznacznym stopniu wynikają z interferencji schematów z języka rodzimego; ich obecność w tekście akademickim jest raczej skutkiem nieopanowania techniki posługiwania się językiem obcym jako takim.

\section{Rodzaje błędów i badany korpus}

Zebrany przeze mnie materiał badawczy, który został wyekscerpowany z korpusu 30 prac dyplomowych (licencjackich i magisterskich), zarówno w ich wersji roboczej jak i finalnej, dowodzi, że większość błędów składniowych w tekstach akademicko-naukowych nie dotyczy samej budowy schematów zdaniowych, lecz raczej sprawnego posługiwania się nimi w różnych kontekstach. W ramach niniejszej pracy nie sposób przedstawić wszystkich kategorii uchybien, jakie wyłaniają się na podstawie znalezionych przykładów, dlatego ograniczę swoje rozważania jedynie do czterech kategorii błędów o największej frekwencji, aby tym samym wskazać na najczęstsze trudności, z jakimi borykają się autorzy-nowicjusze piszący swoje prace naukowe. Będą to deficyty:

- w zakresie stosowania technik nominalizacji i pasywizacji;

- w zakresie podziału wypowiedzi na struktury tematyczno-rematyczne;

- w zakresie szyku zdania;

- dotyczące deformacji znaczeniowej.

Za błąd można uznać uchybienia na płaszczyźnie systemu lub normy. O ile te pierwsze stanowią kategorię błędów, w wyniku których komunikacja jest całkowicie zakłócona, o tyle te drugie nie naruszają ogólnych teorii i reguł gramatyki, ale odwołują się do akceptowalności stylistycznej lub komunikacyjnej. Mamy świadomość tego, że istnieją - szczególnie w obrębie topologii zdania - akceptowalne odstępstwa od ustalonych norm, a właściwie od tzw. reguł preferencyjnych (zob. M.L. Kotin 2007), których naruszenie nie generuje niegramatycznych zdań, a jedynie prowadzi mówiąc językiem O. Behaghela - do zaburzenia syntaktycznej pozycji spoczynkowej (por. ,syntaktische Ruhelage”). Takie przypadki traktowane są jako „stylistyczne wy- 
powiedzi, inwersje, zdania nacechowane emocjonalnie, uwydatniające jakąś informację czy dynamizujące wypowiedź” (A. Duszak 1986: 60). Nasuwa się jednak pytanie, czy dyskurs naukowy jest dobrym miejscem do używania tego typu zdań. W znakomitej większości przypadków nie (zob. M. Drescher 2003), niemniej jednak także i tutaj istnieją konteksty komunikacyjne, w których uzasadnione jest odejście od reguły preferencyjnej $^{2}$.

\subsection{Defektywność w zakresie stosowania technik nominalizacji i pasywizacji}

Jaka skala deficytów w dyskursie studenckim wyłania się na bazie analizy korpusowej? Największe uchybienia nie dotyczą - jak wspomniałam - sprawności poprawnego konstruowania zdań. W większości przypadków, student o przeciętnych kompetencjach językowych jest w stanie wygenerować zdania o rozpoznawalnym schemacie strukturalnym, choć pod względem poprawności w zakresie fleksji czy pisowni odbiegają one często od ideału. Największe problemy i trudności, z jakimi konfrontowani są początkujący piszący, polegają na niedostosowaniu użycia danego schematu zdaniowego do potrzeb komunikacyjnych kontekstu lub wymogów gatunkowych tekstu fachowego. Pod tym kątem prace studenckie odznaczają się niskim stopniem nominalizacji i pasywizacji. Dominują w nich natomiast struktury werbalne, które łączone są w segmenty przypominające opowiadanie i posiadające typową dla tekstów narracyjnych sukcesję czasową:

(1) Meine Magisterarbeit ist eine Art Fallstudie am Beispiel meiner Au-pair Aufenthalte (...) Im Jahre 1999 nahm ich an einem Au-pair Programm teil und verbrachte ein Jahr in Deutschland. Drei Jahre später kam ich als ein Au-pair in die USA und lebte ein Jahr in einer amerikanischen Familie (...) Mein großer Wunsch in die USA zu fahren, englische Sprache zu beherrschen, das Land und Kultur kennen zu lernen, wurde langsam real. Aus der Zeitperspektive kann ich feststellen, dass mein erstes Telefonat viel schwieriger war als ich es erwartete.

(2) Als Gegenstand meiner Überlegungen ist Schule. Seit zwei Jahren, als ich Lehrerin geworden bin, verbringe ich mehr Zeit in der Schulrealität.

Kolejny przykład źródłowy ukazuje cały szereg dylematów, z jakimi zmagał się autor tekstu:

(3) Die oben beschriebenen Konstruktionen sind die typisch auftretenden Sätze. Darüber hinaus entstehen natürlich weitere Konstruktionen. Ich wähle nur diese, die einer Regelmäßigkeit unterliegen. Ein Teil von der Situation, in deren man Komplimente äußert, ist die Beurteilung (positiv oder negativ), aber sie muss dem Komplimentempfänger Freude macht.

Ponownie razi tu nadmierna tendencja do stosowania zdań w stronie czynnej z finitywną formą czasowników głównych. Nawet tam, gdzie użycie diatezy biernej nasuwa się niemalże intuicyjnie, autor tekstu decyduje się na zastosowanie klasycznego

\footnotetext{
${ }^{2} \mathrm{Z}$ uwagi na to, iż ten wątek nie jest bezpośrednio związany z poruszaną problematyką, pozostawiam go bez dalszego komentarza.
} 
schematu zdania w stronie czynnej. W wielu przypadkach, także i tutaj, faworyzowanie stylu werbalnego wynika z braku umiejętności holistycznego, całościowego ujęcia propozycji zdania. Brak ten prowadzi często do opisów peryfrastycznych zamiast mówiąc w przenośni i wprost - do zwięzłego „nazwania rzeczy po imieniu”. A zatem zamiast przedmiotowości danej propozycji zdaniowej wyrażanej przez predykaty nominalne (np. Auswahl der Beispiele, Belegsammlung, Komplimentäußerung, Korpusanalyse) mamy do czynienia ze scenicznościa wypowiedzi kodowanej za pomocą predykatów czasownikowych (np. Ich wähle die Beispiele aus, Ich sammle Belege, Ich analysiere das Korpus, man äußert Komplimente). Jak mogłaby wyglądać korekta powyższego tekstu w kontekście powyższych rozważań? Oto jedna z propozycji:

(3') Die oben beschriebenen Konstruktionen stellen typische Sätze dar. Darüber hinaus lassen sich hier auch andere Satzstrukturen heraussondern, die diesem Schema folgen. Aus der reichen Belegsammlung werden nun diejenigen Kontexte und Sprachbeispiele ausgewählt und behandelt, bei denen eine Regelmäßigkeit festgestellt werden kann. Das sind etwa Verwendungsfälle, in denen Komplimente zur Beurteilung verwendet werden, ganz gleich, ob es sich dabei um eine positive oder negative Bewertung handelt. Wichtig dabei ist allerdings, dass auf die Komplimentäußerung der Empfänger mit bestimmten Emotionen (Freude) reagiert.

Korekta powyższego tekstu polega w gruncie rzeczy na zamianie wyrażeń werbalnych na nominale oraz - rzecz jasna - na dopasowaniu struktury zdania w miejscach, gdzie zamiast czasownika została wprowadzona fraza nominalna. Taka modyfikacja generuje w sposób naturalny potrzebę zastosowania form bezosobowych oraz strony biernej czasownika, dzięki której możliwe jest wykluczenie informacji o agensie, czyli wykonawcy danej czynności. W tekstach naukowych (na płaszczyźnie metakomunikacji) chodzi głównie o predykaty opisujące czynności lub procedury typowe dla działań naukowo-badawczych. Uszczuplenie struktury semantycznej zdania o podmiot działający (w tym przypadku autora tekstu, który analizuje, interpretuje, opisuje, bada, argumentuje, wskazuje itd.) zapobiega niepotrzebnemu powielaniu informacji o autorze-badaczu, a przenosi akcent kodowanej treści na samą czynność analizowania, interpretowania, opisywania, badania, argumentowania, wskazywania itp. Tekst zyskuje przez to charakter naukowy, w którym przecież nie chodzi o podkreślenie roli autora jako podmiotu poznania, ale przede wszystkim o możliwie transparentny przekaz faktów naukowych.

\subsection{Defektywność w zakresie podziału wypowiedzi na struktury tematyczno- rematyczne}

Dość powszechnym zjawiskiem w tekstach studenckich jest defektywność w zakresie podziału wypowiedzi na struktury tematyczno-rematyczne oraz $\mathrm{w}$ zakresie technik anaforyzacyjnych. Wiemy, że w każdej wypowiedzi, która osadzona jest w jakimś kontekście, występują wyrażenia inherentnie tematyczne, czyli znane i inherentnie rematyczne, czyli nowe. Segment wyrażeń rematycznych posiada w danej wypowiedzi największą wartość informacyjną, jest niejako rdzeniem wypowiedzi i dąży do prawostronnego osadzenia w linearnej budowie zdania. Elementy tema- 
tyczne pretendują do statusu przedmiotu wypowiedzi i stoją w związku z tym w pozycji topikalnej zdania. Umiejętność podziału wypowiedzi na segment tematyczny i rematyczny jest zatem kluczową sprawnością, warunkująca prawidłową budowę zdania oraz kształtującą podstawę do parafrazowania jego sensu. Te aspekty mają dla studenta piszącego pracę dyplomową szczególne znaczenie w kontekście rekapitulacji treści zaczerpniętych z literatury przedmiotu. Poszukiwanie sensu wypowiedzi wiąże się dla niego z poszukiwaniem odpowiedzi na pytania: o czym mówi się $w$ zdaniu? (pytanie o temat) oraz co się mówi? (pytanie o remat). Nieporadność w tym aspekcie przekłada się na tendencję do konstruowania zdań, w których mechanizm następstwa tematycznego, czyli tematyzacja rematu nie funkcjonuje, a ciąg następujących po sobie zdań blokuje min. anaforyzację, czego efektem jest wyraźnie odczuwalny brak kohezji, np.:

(4) In meiner linguistischen Forschung werde ich viele von diesen Erscheinungen analysieren. Ich versuche Kreativität auf die Sprachlosigkeit zu beziehen. Die Frage nach dem Wesen und Erscheinungsformen der sprachlichen Schwierigkeiten wurde im Mittelpunkt gestellt.

Przytoczony tekst sprawia wrażenie zbioru luźnych zdań, które - choć są ze sobą połączone referencyjnie przez hipertemat zawarty w tytule tekstu - to jednak nie posiadają tzw. par izotopicznych, czyli elementów budujących zależności semantyczne pomiędzy wyrażeniami w tekście i zapewniających w ten sposób jego spójność. Brak owych semantycznych łączników pomiędzy sąsiadującymi ze sobą zdaniami świadczy z jednej strony o znikomej kontroli autora nad działaniem tekstotwórczym (w myśl zasady: „,piszę wszystko naraz, co wiem”), z drugiej zaś strony wymusza na odbiorcy konieczność interpretacji relacji zachodzących między nimi w oparciu o własną wiedzę pozajęzykową. Spróbujmy dokonać korekty powyższego tekstu poprzez modyfikację zdań w taki sposób, aby zespolić poszczególne zdania w spójną całość tekstową:

(4') Im Rahmen der geplanten Forschung $(i)$ werden viele von den oben erwähnten Erschei-

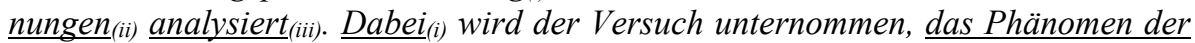
sprachlichen Kreativität dem Problem der Sprachlosigkeit ${ }_{\text {(ii) }}$ gegenüberzustellen. Im Mittelpunkt der Analyse (iii) stehen auch Fragen nach dem Wesen und den Erscheinungsformen der sprachlichen Schwierigkeiten.

Relacje izotopiczne pomiędzy poszczególnymi wyrażeniami zostały oznaczone odpowiednio przez indeks dolny. Na ich podstawie widać wyraźnie, że zdania tekstu nawiązują do siebie nawzajem i w ten sposób tworzą linearny ciąg wypowiedzi powiązanych ze sobą paradygmatycznie. Na bazie tego krótkiego fragmentu tekstu można przekazać studentowi wiedzę na temat różnych relacji izotopicznych:

- repetycja elementów przez proformę (Im Rahmen der geplanten Forschung dabei);

- parafraza przez ekspansję (Erscheinungen - das Phänomen der sprachlichen Kreativität, das Problem der Sprachlosigkeit);

- izotopia przez derywację słowotwórczą utworzoną od użytego wcześniej wyrażenia (analysiert/analysieren - Im Mittelpunkt der Analyse). 
Korekta błędów w tekście studenta powinna zatem być ukierunkowana na przekazanie informacji o błędzie, a w szczególności informacji, na czym polega ów błąd i jakie są sposoby jego eliminowania (np. poprzez zastosowanie prawidłowych relacji tematyczno-rematycznych). Pozostawienie danego błędu bez komentarza lub tylko podkreślenie fragmentu tekstu zawierającego nieprawidłowości nie przyniesie pożądanych efektów. Nie oczekujmy zatem, że student, który nie jest aktywizowany do krytycznego spojrzenia na swoje deficyty tekstowe, wykształci w sobie samorefleksję na temat popełnianych błędów.

\subsection{Naruszenie szyku zdania}

Klasycznym problemem składniowym typowym dla polskojęzycznych studentów germanistyki jest niekonsekwencja w szyku zdań podrzędnych, skoordynowanych względem siebie za pomocą spójników parataktycznych und, aber, oder, a wprowadzonych do zdania złożonego za pomocą spójników hipotaktycznych dass, weil. Oto przykłady:

(5) Man sollte auch nicht außer Acht lassen, dass im Mittelpunkt der Handlung immer die Frau steht und gerade aus ihrer Perspektive wird gewöhnlich die Geschichte aufgerollt;

(6) Gesetzt den Fall, dass ein Empfänger einer Beleidigung bei guter Laune ist und hört sich eine spitze Bemerkung an;

(7) Ich versuche zu erwägen, wie ein sprachliches Bewusstsein aussieht und wie reagieren andere Menschen, wenn sie sich (...).

W obu przypadkach mamy do czynienia z niekonsekwencją w stosowaniu szyku całkowicie przestawnego, typowego dla zdań podrzędnych spójnikowych. O ile w pierwszym zdaniu podrzędnym zachowany jest każdorazowo prawidłowy szyk wyrazów, czyli szyk całkowicie przestawny, o tyle w drugim zdaniu podrzędnym relacja wobec zdania głównego została zachwiana, czego powodem mogło być błędne przekonanie, że zdanie to znajduje się poza strukturą hipotaksy.

\subsection{Deformacja znaczeniowa}

Kolejnym, powszechnie występującym zjawiskiem w akademickich tekstach naukowych jest problem deformacji znaczeniowej. Dotyczy on sytuacji, w których na skutek błędnej lub wadliwej lokalizacji danej części zdania w układzie syntagmy, dochodzi do zaburzenia struktury semantyczno-logicznej i powstania wątpliwości co do sensu całego zdania. Skupmy się na następującym przykładzie źródłowym:

(8) Diese Romane (...) sind keine Liebesromane. Sie sind es vor allem Entwicklungsromane mit hohem moralischem Anspruch (...).

Trudności, jakie mamy z właściwym zrozumieniem sensu cytowanego zdania, wywołane są przez błędnie zastosowany zaimek es, który - jeśli przyznamy mu status orzecznika w roli anafory - deformuje relację logiczną zachodzącą pomiędzy pierwszym a drugim zdaniem. Ostatecznie trudno jest ustalić, czy mamy tu do czynienia z afirmacją czy negacją propozycji zdania pierwszego. 


\section{Podsumowanie}

Umiejętności tekstotwórcze stanowią integralną częścią kompetencji językowej (zob. T. Zuchewicz 2002: 185), bez której komunikacja (szczególnie w świecie nauki) nie byłaby możliwa. Jak każde kompetencje, wymagają one świadomego i systematycznego kształtowania. W tym kontekście nasuwa się pytanie, jakie implikacje niesie ów wymóg dla dydaktyki uczelnianej? Jedną ze strategii dydaktycznych, nad którą warto byłoby się zastanowić, jest wprowadzenie propedeutycznych kursów z piśmiennictwa naukowego. Nadrzędnym celem takich kursów jest stopniowe nabywanie umiejętności posługiwania się językiem (obcym) jako językiem naukowym (,Deutsch als fremde Wissenschaftssprache“ w sensie K. Ehlicha 1993).

Oczywiście: umiejętność sprawnego posługiwania się stylem naukowym w języku obcym to wymóg długoletniej praktyki i szeregu kompetencji, o których była mowa na wstępie. Nawet dla rodzimego użytkownika, język naukowy to osobny rejestr stylistyczny, który należy sobie przyswoić i kształtować przez lata. Dlatego posługiwanie się stylem naukowym w dydaktyce uczelnianej to ciągle - jak twierdzi L. Flower 1990 (cytat za E. Guz 2016: 77) - ,a higher order of discourse which is used as a tool for analysing, constructing, communicating and challenging knowledge in a given subject area". Czy zatem nie za wielkie wymagania chcemy postawić naszym studentom, proponując im udział w takich kursach? Jakkolwiek ważne nie byłyby argumenty przemawiające za pozostaniem przy obecnym ,status quo" (równoległe nabywanie wiedzy fachowej i umiejętności tekstowych w ramach tzw. seminarium dyplomowego), o przyszłości rzeczonych kursów zadecydują sami studenci, z kręgu których słychać coraz głośniejsze postulaty ${ }^{3}$ wprowadzenia dodatkowych zajęć, przygotowujących „do napisania pracy magisterskiej”.

Dydaktyczne rozdzielenie seminarium dyplomowego i kursów propedeutycznych z piśmiennictwa naukowego nie wpłynie negatywnie na powodzenie tego drugiego: Nawet bez biegłej znajomości aparatu teoretyczno-pojęciowego można trenować umiejętności tekstotwórcze oraz kształtować tzw. wyczucie językowe. Rzecz w tym, aby nabywanie uzusu językowego w ramach dyskursu naukowego (np. przez przyswajanie typowych schematów oraz strategii formułowania) rozpocząć na możliwie wczesnym etapie edukacji akademickiej, a nie - jak to ma miejsce w większości przypadków - na kilka miesięcy przed oddaniem pracy dyplomowej. Konkludując należy powiedzieć, że to od nas jako nauczycieli akademickich, od naszego zaangażowania

\footnotetext{
${ }^{3}$ Powołuję się tu min. na ankietę przeprowadzoną wiosną tego roku wśród studentów filologii germańskiej, przygotowujących się do napisania pracy magisterskiej. Respondenci zostali poproszeni o udzielenie odpowiedzi na trzy pytania: 1) Ile prac o charakterze naukowym napisał/a Pan/Pani dotychczas? 2) Co stanowiło dla Pani/Pana największą trudność? 3) Jakiej formy pomocy życzyłby/życzyłaby Pan/Pani sobie podczas przygotowania pracy magisterskiej? Z ankiety wynika min., że 90\% studentów studiujących na drugim stopniu napisało w ciągu całej swojej edukacji akademickiej jedną bądź dwie prace o charakterze naukowym. Największą trudnością przy przygotowaniu pracy licencjackiej stanowiło prawie dla wszystkich ankietowanych „formułowanie zdań o charakterze naukowym”. Życzeniem większości ankietowanych są zajęcia, które pokazałyby „w sposób praktyczny, jak (na-)pisać teksty naukowe".
} 
w proces dydaktyczny zależy w dużej mierze, na jakim poziomie socjalizacji tekstowej nasi studenci zakończą swoją edukację.

\section{Bibliografia}

Cirko, L. (2009), Akceptacja w komunikowaniu się. Między preskryptywizmem a permisywizmem. Wrocław.

Cirko L. (2013), Deutsch als Sprache der Wissenschaft aus der Sicht eines Auslandsgermanisten, (w:) Deutsch in den Wissenschaften. Beiträge zu Status und Perspektiven der Wissenschaftssprache Deutsch. München, 72-77.

Clyne, M. (1987), Cultural differences in the organization of academic texts, (w:) „Journal of Pragmatics“ 11, 211-247.

Drescher, M. (2003), Sprache der Wissenschaft, Sprache der Vernunft? Zum affektleeren Stil in der Wissenschaft, (w:) S. Habschied / U. Fix (red.), Gruppenstile. Zur sprachlichen Inszenierung sozialer Zugehörigkeit. Frankfurt am Main, 53-79.

Duszak A. (1986), Niektóre uwarunkowania semantyczne szyku wyrazów w zdaniu polskim, (w:) „Polonica” XXII, 59-74.

Ehlich, K. (1993), Deutsch als fremde Wissenschaftssprache, (w:) „Jahrbuch Deutsch als Fremdsprache“ 19, 13-42.

Flower, L. (1990), Negotiating academic discourse, (w:) L. Flower/ V. Stein/ J. Ackerman et al. (red.), Reading-to-write: Exploring a Cognitive and Social Process. New York, 221-252.

Gajda S. (2001), Styl naukowy i jego socjokulturowy kontekst, (w:) J. Bartmiński (red.), Współczesny język polski. Lublin, 183-199.

Guz, E. (2016), Learner Perception of Academic Register at the Undergraduate Level, (w:) H. Chodkiewicz./ P. Steinbrich/ M. Krzemińska-Adamek (red.), Working with Text and Around Text in Foreign Language Environments. Cham, 75-88.

Kotin, M.L. (2007), Die Sprache in statu movendi. Sprachentwicklung zwischen Kontinuität und Wandel. T. 2: Kategorie - Prädikation - Diskurs. Heidelberg.

Kretzenbacher, H.L. (1991): Syntax des wissenschaftlichen Fachtextes, (w:) „Fachsprache“ 13/ 3-4, 118-137.

Leki, I./ A. Cumming/ T. Silva (2008), A synthesis of research on second language writing in English. New York: Routledge.

Olszewska D. (2009), Teksty naukowe jako przedmiot badań tekstologicznych, (w:) Z. Bilut-Homplewicz/ W. Czachur/ M. Smyk (red.), Lingwistyka tekstu w Polsce i w Niemczech. Pojęcia, Problemy, Perspektywy. Wrocław.

Zuchewicz, T. (2002), O pisaniu w języku obcym, internecie oraz autonomii studentów filologii germańskiej, (w:) W. Wilczyńska (red.), Wokół autonomizacji w dydaktyce języków obcych. Badania i refleksje. Poznań, 184-185. 